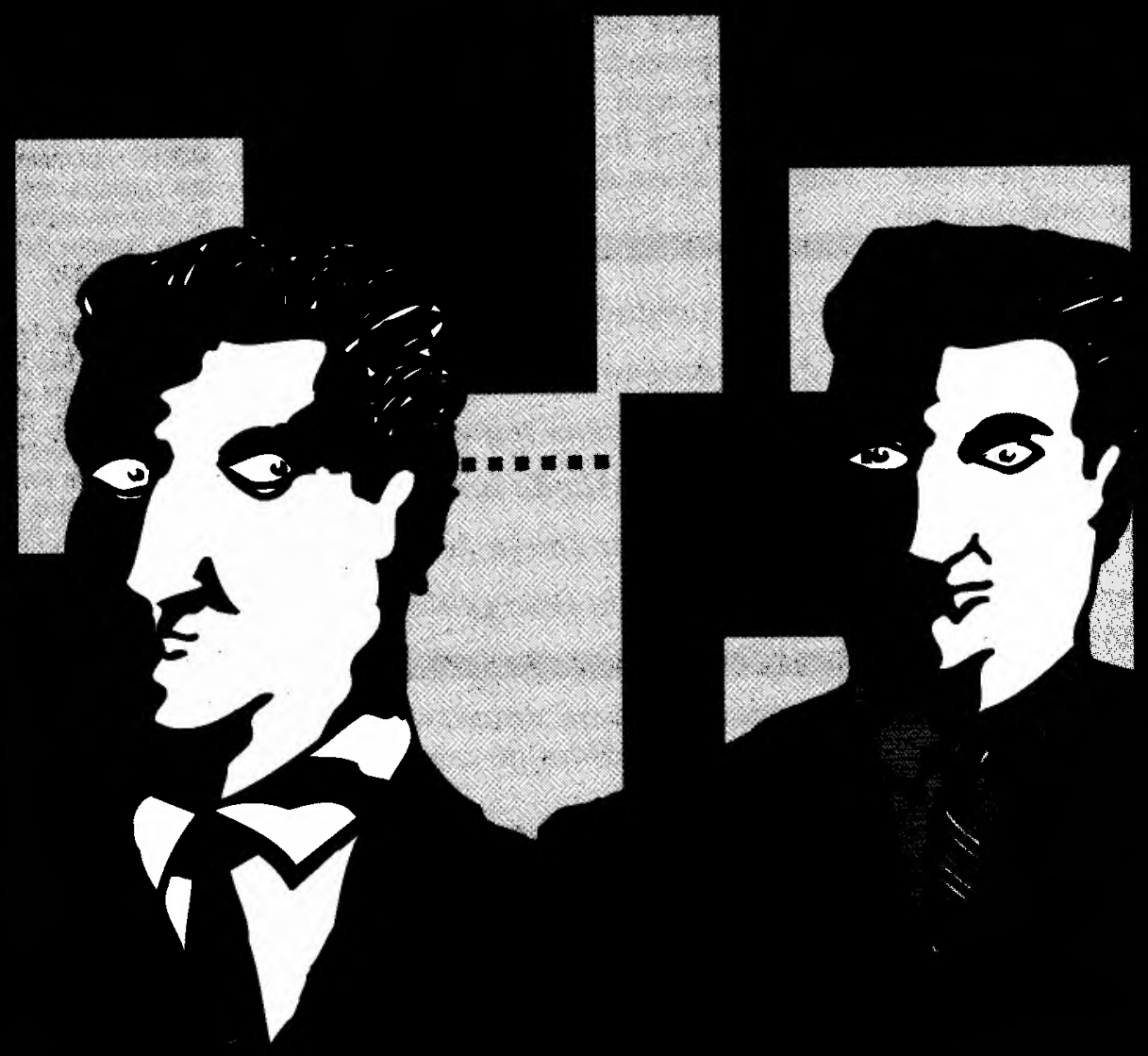

\title{
SOBRE O ENVELHECIMENTO GERENCIAL
}

\section{noberto Grun}

Professor do Departamento de Engenharia de Produção da Universadade Federal de São Carlos e Pesquisador do IDESP.

* RESUMO: Neste artigo, pretende-se tratar das formas de envelhecimento observadas no campo gerencial, dando especial enfoque ao conflito geracional. Argumenta-se que este gênero de disputa é um importante produtor de dinâmica na vida das organizaçóes, tendo forte poder explicativo no esclarecimento dos processos de mudanças organizacionais e tecnológicas. $O$ texto mostra as diferenças entre idade cronológica e idade social, levantando formas através das quais coortes mais jovens de gerentes tentam fazer envelhecer aqueles que os precederam e algumas maneiras encontradas por estes últimos para se contrapor à ofensiva das novas gerações.
* PalavRas-CHaVe: Executivos, conflitos geracionais, associações de executivos, ética.

* ABSTRACT: This paper deals with the managerial's aging pointing specially it the generational conflit. It sustains that this kind of dispute is a very important producer of dynamics in the organizational life, explaining some processes of bureaucratic and technological changes. The text shows the distinction between the chronological and the social age, showing the way the young gereration of managers attemtps make their elders grey and some weapons that the old generation found to resist the attack of the youngsters.

* KEY WORDS: Managers, generation conflict, managers's associations, ethics.

São Paulo, 33(2):44-63

Mar./Abr. 1993 
Neste artigo, pretendo desenvolver a idéia de que o envelhecimento gerencial é um processo socialmente induzido e marcado principalmente pela luta entre gerações de gerentes. Por outro lado, grupos de gerentes conseguem, de diversas formas, de acordo com seus respectivos backgrounds retardar esse processo, ou mesmo transformá-lo em trunfo pessoal. O estudo desse tipo de fenômeno, além de ajudarnos a compreender uma boa parcela dos conflitos organizacionais realmente existentes, habilita-nos a melhor perceber de onde aparecem os impulsos modernizadores existentes nas empresas, bem como as fontes de resistência que aparecem no dia a dia dos processos de concepção e implantação de inovações dentro delas ${ }^{1}$.

Minha análise desses processos foi realizada a partir de entrevistas com membros de associação de executivos profissionais e balizada por pesquisas anteriores sobre processos de mudança organizacional a nível de empresas individuais. Nesse tipo de démarche, os principais dados trabalhados são as falas dos indivíduos envolvidos nos processos de difusão de novos padrões de gestão. Elas serão submetidas a uma grade sócio-linguística. Seguindo um caminho indicado por Bourdieu ${ }^{2}$, minhas deduções surgirão a partir das oposições de sentido encontradas internamente ao discurso de cada ator e na contraposição entre atores.

Um bom registro da dinâmica geracional que corta o mundo das administrações passa por um rápido apanhado da história empresarial brasileira dos últimos 40 anos, que irá enquadrar o campo gerencial que estudamos. As chamadas organizações "complexas" ${ }^{3}$ são uma evolução recente do tecido econômico brasileiro, sobretudo se nos limitarmos ao seu setor privado. No período pré 64 , elas eram raras exceções no panorama industrial e comercial.

Mesmo no setor financeiro, embora já pudessem ser observadas grandes organizações, elas ainda não tinham adotado os principais traços das chamadas organizações modernas.

Os complexos empresariais atualmente existentes apareceram quer através da mutação interna das antigas organizações pré-monopolistas ${ }^{4}$, quer através da implantação no Brasil de filiais de grandes empresas multinacionais, quer pela rápida evolução de empresas brasileiras mais modestas que souberam se adaptar às linhas de força a que estava submetido o campo empresarial depois do golpe de 1964. A partir destas origens diversas, as empresas convergiram para o padrão organizacional então paradigmático a nível internacional, que poderíamos descrever em uma palavra como a

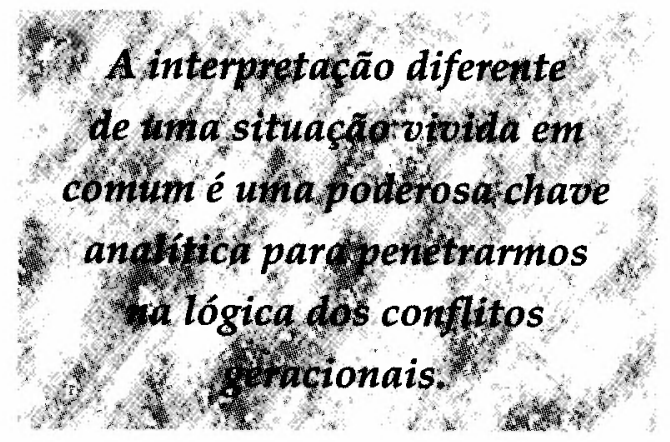

da departamentalização. Para caracterizar este momento, podemos buscar o grande best seller da literatura gerencial brasileira dos anos 60 e início dos 70, os Princípios de Administração, de Koontz \& $\mathrm{O}^{\prime}$ Donnell ${ }^{5}$ que descrevia e prescrevia a departamentalização como a grande receita gerencial.

Posteriormente, já no fim dos anos $70 \mathrm{e}$ início dos 80 , sob o impacto da automação de base microeletrônica, começa a se esboçar um novo paradigma, ainda não perfeitamente definido, mas que passa pelo aprofundamento do processo do sistema de substituição de mão-de-obra por máquinas "inteligentes", tanto no trabalho de transformação de matéria, quanto, agora mais profundamente, no trabalho burocrático de forma geral 6 .

Esquematicamente, cada uma das três épocas que assinalamos gera um tipo específico de economia pulsional ${ }^{7}$ que produz seus agentes organizacionais típicos, ao mesmo tempo que os hierarquiza em função da sua capacidade de interiorizar os constrangimentos do tempo assinalado e agir em conformidade a ele. Os novos padrões surgem em contraposição aos existentes, mas, à medida que os anteriores já se enraizaram nas instituições e nos atores, as configurações concretas observáveis sempre se apresentam como uma mistura complexa entre o mais recente e os modos de organização anteriores ${ }^{8}$.
1. Em outro texto discuto algumas linhas de produção da dinâmica de mudanças organizacionais produzidas a partir de conflitos intrageracionais.

2.BORDIEU, P. Ce que parler veut dire. Paris: Fayard, 1982.

3. ETZIONI, A. Organizações complexas. Rio de Janeiro: USAID, 1967.

4. REISS, G. Development of Brazilian industrial entreprise, a historical perspective, Berkley, 1980. (Tese de Doutoramento). 0 autor analisa esta evolução para três grandes empresas brasileiras do período anterior a 1964 - a Matarazzo, a Votorantim e a Villares, que realizaram esta transformação com um grau muito distinto de sucesso.

5. KOONTZ, H.; O'DONNELL,C.: Principio de administração: uma análise das funções administrativas. São Paulo: Pioneira, 1962.

6. KAPLINSKY, R. Automation, the technology and society. Harlow: Longman, 1984.

7. 0 conceito de "economia pulsional", empregado na sociologia histórica por ELIAS, N. La dynamique de l'Occident. Paris: Calmann-Levy, 1975; desde a década de 30 fornece uma boa solução provisória para a ligação problemática entre os niveis macro e micro sociológico, que continua sendo uma questão de fronteira na disciplina.

8. VILLETTE, M. L'homme que croyaitau au management. Paris: Seuil, 1988. 
9. FAORO, R. Os Filhos da FoIha. Porto Alegre: Globo, 1979.

10. Este fenômeno é análogo ao "isomorfismo mimético" proposta por POWEL, W.W.; DIMAGGIO, P.J. The new institutionalism in organizational analysis. Chicago: University of Chicago Press, 1991.

11. A análise se complica um pouco porque 0 investigador não está tăo advertido da necessidade de objetivação para este tipo de conflito, quanto já está para outras formas de exibição da dinâmica social. Aqui, ele tem muitos traços de socialização em comum com uma das classes de agentes, tendendo assim a considerar "universais" alguns pontos de visita de seus coetâneos.

12. SEGNINI, L. Bradesco: A liturgia do poder. São Paulo: PUCSP, 1986. (Tese de Doutoramento).
No Brasil, do início do processo de constituição das organizações complexas, o único padrão existente para absorção e /ou comparação era o da Administração Pública, já parcialmente cindido entre o setor da Administração Direta, considerado pouco eficiente, onde reinavam, pelo menos no imaginário, os "filhos da folha" ${ }^{\prime \prime}$, descendentes diretos da administração colonial portuguesa e o setor indireto, representado na época principalmente pelo Banco do Brasil e menos caracteristicamente pela então nova $\mathrm{Pe}$ trobrás, organizações que eram consideradas modelo, gozando de prestígio e aparentando dinamismo e eficiência.

Para a maioria dos agentes envolvidos na primeira vaga de transformação das empresas privadas já existentes em organizações modernas, este primeiro modelo foi vivenciado de maneira ambígua, ao menos emquanto referência a ser imitada e a ser ultrapassada ${ }^{10}$. Não é assim por acaso que eles se definem, no mais das vezes, como funcionários das empresas em que trabalham ou em que trabalharam, em contraposição aos operários ou peões, de acordo com as terminologias locais.

Para os agentes que se engajaram nas organizações no nosso "segundo tempo", o estilo "funcionário" é totalmente estigmatizado e se, inadvertidamente, o pesquisador cataloga um desses agentes naquela rubrica, ele terá diante de si um interlocutor enfurecido. Ao contrário de seus predecessores, eles são gerentes ou executivos. Agora, funcionário passa a ser sinônimo de burocrata, de pessoa estética, ultrapassada etc. A análise se depara assim com uma distinção infinitesimal e aparentemente destituída de sentido para o observador externo, mas ela é vivenciada pelos atores como o ponto da última diferença, que separa as duas classes significativas de agentes com suas propriedades sociais típicas, não perfeitamente explicitadas, mas intensamente sentidas pelos que as vivem. Correlativamente, os "funcionários" tentam fazer prevalecer a não existência de distinção jurídica entre o estatuto dos dois grupos para afirmar a sua similitude real, e, portanto, a igualdade de chances e de prestígio. Diante desta linha de argumentação, os seus sucessores só encontram mais uma afirmação do apego dos "funcionários" a normas envelhecidas e já desprovidas de sentido, como mais uma prova da separação real das duas classes de agentes. Poderíamos inclusive dizer que a interpretação diferente de uma situação vivida em comum é uma poderosa chave analítica para penetrarmos na lógica dos conflitos geracionais. ${ }^{11}$

\section{O NOVO E O VELHO: RESISTÊNCIA E ADAPTAÇÃOO}

À medida que as situações pesquisadas no nível micro não estão suspensas no ar, mas suportadas pela sociedade inclusiva, no mais das vezes o sentido prevalecente de cada situação pontual estará dado pelo maior ou menor enraizamento de cada interpretação no imaginário social e principalmente nas fontes mais dinâmicas de produção e divulgação de idéias e de imagens. No Brasil empresarial do fim dos anos 70 e começo dos 80 , quase totalmente penetrado pelos critérios de excelência do estilo norte-americano, onde um dos maiores valores é o da liderança jovem - fica fácil ver para onde soprou o vento que sobredetermina grande parte dos conflitos organizacionais ocorridos no país.

Podemos comprovar indiretamente a força do paradigma dominante observando a reação dos grupos empresariais que pretendem manter uma administração "à antiga". Para conseguir esta finalidade, eles são obrigados a criar verdadeiras instituições totais, à medida do possível isoladas do meio empresarial dominante. $O$ Bradesco, aparece como um exemplo acabado e bem-sucedido desta tendência, faz frente ao desafio do paradigma dominante através da produção de um impressionante sistema de auto-reprodução interna. Ele começa com escolas em regime de semi-internato localizadas nas zonas menos privilegiadas do país e culmina, atualmente, na "Cidade de Deus", onde moram e trabalham uma boa parte de seus funcionários e localiza-se mesmo uma escola de terceiro grau voltada para a transformação dos quadros internos do grupo ${ }^{12}$.

Em relação ao nosso "terceiro tempo", a inflexão do processo de automação, a análise geracional centrada na associação de executivos não forneceu indicadores 
de qualidade, uma vez que os novos agentes organizacionais não estão bem definidos, sem entidades que os congreguem tipicamente. Por exemplo, a multiplicidade de organizações que pretendem agrupar agentes em torno da maestria do processo de automação demonstra a incipiência do processo.

Os diversos tipos de agentes encarnam épocas sucessivas das organizações e seus respectivos constrangimentos tecnológicos e organizacionais. Para explicar estes grandes cenários, entram em choque duas ordens de propostas concorrentes. A primeira delas é o determinismo tecnológico, que oferece à variável exógena tecnologia o primado das explicações dos rearranjos dos processos de trabalho e conseqüentemente das hierarquias estabelecidas entre seus comandantes. A segunda ordem de explicações é o determinismo social, que dá a primazia aos fatores endógenos às situações sociais analisadas.

Numa zona do campo intelectual onde se defrontam profissionais oriundos de áreas de conhecimento até então distantes, com tradições de pesquisa e análise construídas de acordo com lógicas desconectadas entre si, cada uma delas acostumada a privilegiar fatores diferentes, essa discussão passa fundamentalmente pela qualificação do formulador do discurso científico legítimo sobre o assunto. Assim sendo, parece mais pertinente trazer a questão da ordem dos fatores explicativos das mudanças organizacionais para o campo da sociologia dos intelectuais do que a sua manutenção na esfera dos estudos sobre trabalho e organizações. No mais das vezes, a "evidência científica" instituída por cada trabalho isolado reflete respostas já predeterminadas pelo próprio desenho da pesquisa em que ele se ampara, pela forma com que ela constrói o objeto estudado. No nosso caso, trabalhando a partir dos atores e de suas organizações, fica "automaticamente assegurado" o triunfo da série de explicações endógenas.

Antes de polemizar, basta-nos apontar que qualquer tecnologia é inerte sem seus aplicadores e que ela será tão mais desruptiva quanto mais interesses divergentes estiverem em jogo. Neste desenho os atores constroem o alcance $e$ as possibilidades das tecnologias organizacionais ou industriais.

\section{A SOCIOLOGIA DAS GERAÇÕES}

Atribuindo ao contexto social o status de variável explicativa e à tecnologia o de variável dependente, o conflito geracional ganha uma grande amplitude explicativa. A sociologia das gerações não goza atualmente de grande prestígio, talvez pela dificuldade da definição científica de seu objeto, que resvala freqüentemente na

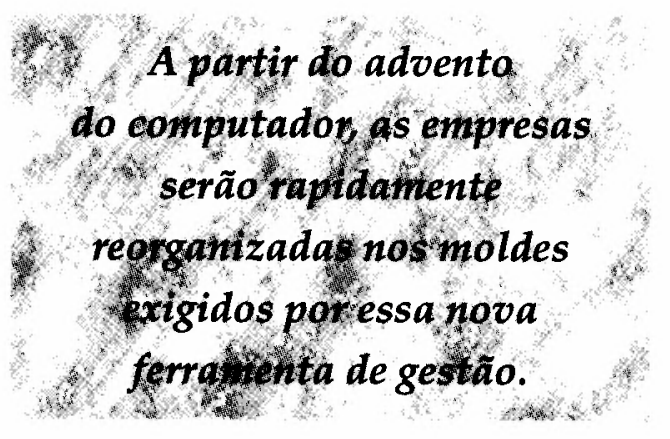

conceituação do senso comum, além da dificuldade de se tratar a questão em termos macroestruturais. A sua riqueza aparece muito mais no campo dos estudos culturais, para caracterizar grupos de intelectuais ou mesmo de políticos.

Neste texto, minha proposta é estender o seu uso para enquadrar questões organizacionais. Para isso, é necessário retrabalhar um pouco os conceitos forjados para dar conta de outras situações.

Podemos dar ao conceito de geração a idéia de um conteúdo cognitivo comum que é vivenciado por um grupo de atores e imposto pela História, através de um feixe de constrangimentos vivido indistintamente por todos os atores que passaram pela mesma experiência na mesma etapa da vida. Este tipo de análise só pode ser operativo quando pensamos em indivíduos vivendo num meio social relativamente homogêneo e vislumbrando expectativas de futuro análogas. Diferentes agentes, coetâneos cronologicamente, irão divergir fortemente na sua idade social, à medida que as diferentes classes sociais e respectivas frações dão um significado diverso e periodizam também de forma diferente as várias etapas da vida pessoal de seus membros.

A partir das experiências realizadas na URSS da década de 1920 pela equipe de Psicologia Cognitiva de Vygotsky ${ }^{13}$ onde se esclareceram as interações entre pen-
13. VYGOTSKY, L. S. A formação social da mente. São Paulo: Martins Fontes, 1984. 
14. BERNSTEIN, B. Languagem et classes sociales. Paris: Minuit, 1977.

15. ATTIAS-DOFUNT, C. Sociologie des generations. Paris: PUF, 1988.

\section{BERNSTEIN, L. Op. cit.}

17. DUBY, G. Au XII siècle: Les 'jeunes' dans la societé aristocratique. Annales, vol. 19, $n^{0} 6$, p. 835-846, 1964. samento e linguagem na interiorização da estrutura social pelas crianças, Bernstein ${ }^{14}$ irá desenvolver a noção de códigos de apreensão e de exteriorização, que podem ser tipificados tanto a nível geracional quanto a nível da posição da família da criança na estrutura social. A partir desta conceituação, onde se imbricam as ordens afetivas e racionais do aprendizado, a Sociologia das Gerações irá encontrar guarida para, caminhando na linha do construtivismo social, fornecer instrumentos de análise para a determinação dos cortes significativos entre as idades ${ }^{15}$.

Para os fins de meu trabalho, a seqüência de estudos citada alicerça: primeiro que os atores constroem quadros de referência mais ou menos complexos em suas socializações primárias, onde elas encaixam o rol das experiências vividas, que são modais para cada classe social relevante. Nas classes mais abastadas, as crianças tendem a desenvolver vários níveis de análise, que Bernstein ${ }^{16}$ chama de código elaborado, passando da ordem de vivência cotidiana à ordem da abstração intelectual quando a situação assim o exigir, a partir do desenvolvimento mimético das habilidades já possuídas por seus progenitores; já nas crianças das classes baixas, só se desenvolve bem o código da vivência cotidiana, chamado pelo mesmo autor de "código restrito", que será utilizado indistintamente em todas as situações. Os desenvolvimentos do quadro intelectual abstrato em fases posteriores da vida é bastante improvável, dada a inércia produzida pelos investimentos afetivos e de adaptação a um mundo difícil de ser vivido, o que marca em geral os limites do aprendizado do tipo autodidata. Segundo: a dimensão geracional do processo aparece justamente no cruzamento entre as ordens afetiva e racional da vivência, quando os acontecimentos que marcarão as gerações serão necessariamente distintos, e conseqüentemente a produção dos quadros de linguagem que referendam o equipamento cognitivo dos agentes, gerado nesta convergência, será geracional. Terceiro: a partir dos códigos divergindo em função de seu portador, o significado imputado a cada fenômeno social relevante pode ser fundamentalmente distinto, segundo a geração do autor em questão.

\section{TIPOS DE CONFLITOS GERACIONAL}

Carregando os três pontos acima e cruzando-os com desenvolvimentos produzidos nos estudos sobre estatutárias e culturais, podemos conceituar dois padrões de conflito geracional significativos para a nossa análise. O primeiro deles inspira-se na análise de Duby ${ }^{17}$ sobre as sucessões aristocráticas no Maconnais medieval. Mostra-nos aquele autor que o pertencimento à categoria dos jovens ou dos seniors e principalmente o comportamento esperado e efetivo dos agentes daquelas coortes não era ditado por sua idade cronológica, mas sim pelo tipo de inserção momentânea que eles tinham naquela sociedade.

Assim, os herdeiros presuntivos e seus séquitos eram mantidos num estado de turbulência e de aventuras constantes que, além de desafogar o congestionamento das linhas sucessórias pela morte prematura de alguns pretendentes, mantinha-os afastados de suas herdades até o momento da passagem do cetro e do feudo, quando podiam casar e assentar praça.

Aquele momento era ditado fundalmentalmente pelo estado do então ocupante principal da herdade. Somente com a sua morte ou declaração de incapacidade física e intelectual é que as sucessões e conseqüentes mudanças de papel e de comportamento efetivo se processavam.

É claro que os herdeiros tinham todo interesse em apressar o momento da passagem forçando a intepretação da incapacidade de seus genitores ou, no limite, eliminando-os, enquanto que os últimos faziam todo o possível para afastá-los de seus feudos, criando desta forma uma forte dinâmica conflitual.

A passagem entre os papéis era assim muito mais ditada pela idade social do que pela idade cronológica dos agentes, cujo estatuto estava prestes a mudar, moldando tanto a physique quanto a psyque du rôle. Numa sociedade fechada que mal se mantinha em situação de reprodução simples, aqueles conflitos opunham simplesmente posições diversas num jogo de soma zero. Assim, em termos de criação institucional ou de complexificação da malha social, estes conflitos eram poucos significativos, mas mos- 
tram-nos claramente a importância de se dissorciar o conceito de idade cronólogica do conceito de idade social. Realiza-se assim uma ruptura com o senso comum, que costuma estabelecer direta e biunivocamente a relação entre uma idade cronológica e uma expectativa de comportamento. Para o presente estudo, onde constatamos a presença de agentes coetâneos, em posição similar, se observados a partir de uma lente macro, mas colocados em microposições organizacionais concorrentes e principalmente, sendo o fruto de modos de socialização diversos, a idéia de pensar o conflito geracional enquanto o conflito entre modos diferentes de se ocupar a mesma posição fornece um ótimo instrumento de análise. Esbarramos desta forma nos limites da analogia com a situação analisada por Duby ${ }^{18}$. Lá, tratava-se de um tipo de luta onde variava apenas a posição dos agentes, mas não a concepção básica de como o papel deve ser desempenhado na disputa pelo direito do mesmo senhorio, que não mexe nas estruturas da sociedade, produzindo pouca ou nenhuma novidade institucional. Por isso chamamos essa modalidade de conflito de gerações de estática.

Outro tipo de conflito, analisado semanalmente por Schorske ${ }^{19}$, é mais importante para nossos propósitos. Discutindo a Viena fin-de siècle, o autor vai nos revelar o conflito de gerações que explica a trama social responsável pela aparição de uma coorte ímpar de intelectuais, uma geração que foi de Klimt a Freud passando por figuras não menos gigantescas como Kraus. Numa sociedade ainda fechada, mas em processo de abertura, onde as possibilidades de inserção nas antigas posições existentes estão bastante prejudicadas pela ação ainda eficaz de seus antigos ocupantes, essa nova geração será obrigada a criar novas posições, criando um jogo de soma positiva. Estas situações favorecem muito a criação explosiva de novidades e facilitam a sua difusão, já que os novos criadores são justamente a expressão avançada de toda uma geração insatisfeita. Desta forma, os antigos padrões de excelência são terrivelmente contestados e o modo de reprodução ainda vigente aprofunda a sua crise, afinal já revelada pela simples incapacidade de absorver os recém-chegados, fornecendo-lhes posições institucionais.

Abrem-se espaços para a venda de "novos peixes", embora os antigos comerciantes possam impugnar as novidades como "obras de camelôs". Como o espaço daquela Áustria majoritariamente católica e agrária era bem limitado, a nova geração intelectual será obrigada a extravasar o seu dinamismo, convertendo-se numa diáspora que irá fecundar toda a cultura ocidental. Este tipo de conflito ultrapassa de longe os limites paroquiais do primeiro tipo, pondo em choque indivíduos oriundos de diferentes arranjos familiares os quais, por sua vez, são expressão de modos de socialização diversos, que se expressam em diferentes habitus.

Agora, os novos atores entrarão em cena principalmente através da redefinição dos papéis e portanto dos cargos e das maneiras do seu preenchimento. Daí darmos à esta modalidade de conflito a denominação de dinâmica. Para os nossos propósitos, esta modalidade terá um forte poder explicativo, a partir das similitudes entre a situação descrita por Schors$\mathrm{ke}^{20}$ e nosso objeto.

\section{AS GERAÇÕES E 0 DETERMINISMO TECNOLÓGICO}

Os conflitos geracionais expressam-se atualmente nas empresas e organizações econômicas, em geral através de grandes subversões nos ambientes de trabalho. Elas são vivenciadas pelos seus atores como decorrências implacáveis dos constrangimentos tecnólogicos. Assim, as sentenças de decadência social são em geral travestidas de "envelhecimento profissional gerado pela incapacidade de adaptação às novidades tecnológicas e informáticas". As promoções sociais ensejadas pelo reverso do processo, são vistas como se tratando do efeito da "capacitação técnica dos promovidos". Olhando estas situações mais detidamente, encontraremos traços geracionais bem delineados, tanto nas coortes vencedoras, quanto nas perdedoras.

Resguardadas as condições prosaicas do universo que estamos tratando, surgem fenômenos análogos aos discutidos por Schorske. O rápido processo de difusão de novidades tecnológicas, de gestão
18. DUBY, G. Op. cit.

19. SCHORKE, C. Conflit de générrations et changement cuturel. Réflexions sur le cas de Vienne. Acts de la Recherche en Sciences Sociales, $n^{2} 26-27, p$. 109-116, 1979.

20. SCHORKE, C. Op. cit. 
21. GRUN, R. Armênios em São Paulo: negócios \& famílias. São Paulo: Sumaré, 1992.

22. GRUN, R. A produção de uma empresa moderna: os bancários e a aotumação. São Paulo: PUCSP, 1985. (Dissertação de Mestrado). e também sociais, pode ser explicado a partir da grade geracional. Gerações sucessivas de agentes das classes médias, não encontrando mais espaço para a reprodução simples das posições ocupadas por seus ancestrais, ou simplesmente já vislumbrando a impossibilidade de conseguir os rendimentos esperados nas gerações passadas para seus investimentos em educação - seja porque estas posições não existem mais na economia monopolizada, seja por que elas perderam o prestígio relativo que gozavam anteriormente, principalmente no que tange aos filhos de comerciantes e rentistas - irão dirigir toda a sua energia social para a criação de espaços nas novas organizações que surgem justamente com a monopolização da economia. Embora a ação dos mecanismos econômicos aumente a deserdação nas classes médias, podemos ainda ver uma super-representação estática de jovens descendentes de imigrantes judeus nas confecções "de ponta", assim como os descendentes de armênios no comércio de calçados, também de luxo e os descendentes de árabes num comércio de tecidos e armarinhos, diferente de outras épocas, mas ainda comércio de tecidos ${ }^{21}$. Esta atualização das heranças, com a adaptação relativa dos novos agentes aos novos tempos é um fascinante campo para o estudo da reprodução social. Aplicadas num momento oportuno, as energias destes diversos setores da mesma coorte geracional contribuirão para alargar imensamente os espaços de inserção possível dos agentes, robustecendo o universo organizacional e dinamizando o tecido econômico como um todo.

Nas organizações já existentes e no aparelho de Estado, esta é também a época da introdução dos primeiros computadores e dos sistemas de gestão a ele associados. Este cruzamento com as novas possibilidades instrumentais resultou no principal bonde tecnológico que os agentes da nova geração pegaram. Assim, eles saíam motorizados para uma corrida em que seus concorrentes autodidatas só andavam a pé. A partir do advento do computador, as empresas serão rapidamente reorganizadas nos moldes exigidos por essa nova ferramenta de gestão.

Seguindo um padrão internacional recontextualizado pelos condicionantes in- ternos brasileiros, as organizações irão procurar avidamente os quadros técnicos com formação análoga a de seus correspondentes nos países centrais e pela primeira vez, irão encontrá-los na quantidade demandada. Esse cruzamento de séries causais relativamente distintas aparece freqüentemente nos agentes que viveram esta época organizacional. Os primeiros quadros bem formados que engajaram-se nas empresas em rearticulação, tiveram em geral carreiras fulminantes. As suas trajetórias pessoais são tomadas como referência pelos executivos mais jovens com mesma formação, que irão tentar conseguir os seus passos de uma maneira praticamente mimética ${ }^{22}$. Aqueles "grandes executivos" passam em geral ao largo das associações de executivos, dispondo de um capital de reconhecimento profissional próprio, sendo em geral considerados mais do que simples financistas ou mercadólogos, antes são considerados portadores de uma visão de conjunto dos problemas empresariais, que os coloca ao campo superior da administração estratégica.

O principal atributo da nova geração passa a ser a contemporaneidade tecnológica. Os constrangimentos advindos do choque geracional irão encarregar-se de fazer estes jovens encarnarem aquela característica e demonstrá-la em todos os momentos, dando a este trunfo a maior rentabilidade possível. Assim, exacerbam-se as diferenças entre os recém-chegados e os antigos ocupantes, ou postulantes aos cargos que existem ou estão surgindo. Neste processo, as novidades técnicas e organizacionais encontram os canais ideais para escoarem dos seus locais de gestação nos países centrais para os de importação no país e posteriormente para os vasos capilares nas empresas, montadas nos novos agentes engajados nesses processos de lutas geracionais.

No nível simbólico, toda a ética nas carreiras autodidatas é posta em xeque no conflito que opõe polarmente a técnica dos novos executivos contra a lealdade dos antigos funcionários. Estes últimos, no mais das vezes, perdem até a capacidade de expressar o seu descontentamento, tamanha é a violência simbólica posta em marcha no processo, que não se trava simplesmente em cada ambiente organi- 
zacional isolado, mas ganha uma dimensão societal com a atuação onipresente dos meios de comunicação de massa. Esta perda de voz explícita de toda uma geração de agentes organizacionais acaba gerando um extremo pessimismo nos melhores membros desta coorte, que foi bem explorado politicamente por figuras como Jânio Quadros (JQ), que pregavam a volta aos valores típicos da época de sua plenitude. Podemos notar o apego desta camada de agentes a JQ nas eleições para governador do estado de São Paulo em 1982, num momento em que aquele personagem era extremamente estigmatizado pelos novos agentes que detinham as principais posições na organização estudada, sem que isso diminuísse nem suas convicções nem seu entusiasmo em defender o líder de sua geração ${ }^{23}$.

\section{CONFLITO GERACIONAL NAS ASSOCIAÇÕES DE EXECUTIVOS}

$O$ conflito geracional entre os dois tipos de agentes fica nítido e adquire certa generalidade, quando as suas respectivas éticas enquanto profissionais e enquanto representantes de seus pares. Ele revela não só as diferentes expectativas pessoais como também os estilos de atuação postos em prática nas empresas.

Documentamos o aparecimento de conflitos geracionais como a forma básica de enfrentamento através do qual se processam mudanças organizacionais profundas, em organizações tão díspares como sindicatos operários altamente mobilizados que articulavam novas modalidades de greves e bancos multinacionais que aprofundavam o seu processo de automação ${ }^{24}$. Naquelas análises, $o$ horizonte eram os resultados concretos da comparação "organização antes e organização depois". Na pesquisa extensiva centrada nas diversas associações de executivos, não podemos documentar com nitidez suficiente esses processos que só adquirem inteligibilidade quando observados em série temporal. Mas pudemos coletar material bastante rico para uma comparação em corte, centrado nas questões de visão de mundo e ética. Uma vez cruzadas essas novas informações com os resultados anteriores, podemos ter uma reconstrução comparativa rica o suficiente para generalizar alguns aspectos simbólicos que marcam os conflitos geracionais e a sua ligação, por vez bem direta, com o comportamento material de nossos agentes.

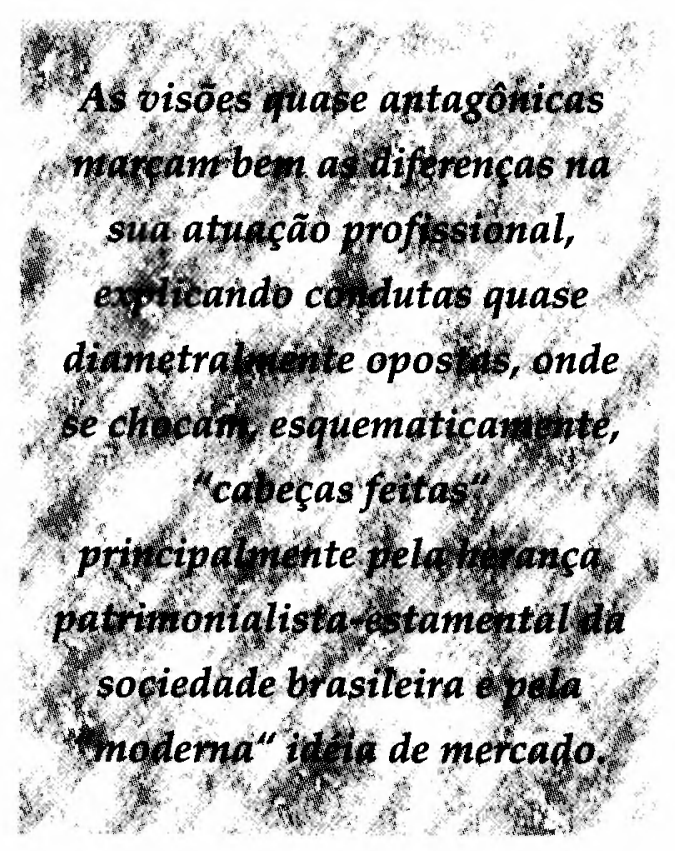

$\mathrm{Na}$ pesquisa que sustenta mais diretamente este trabalho, entrevistei os atuais presidentes das associações e quando possível, algum de seus membros fundadores. Apresento aqui uma contraposição paradigmática, possível de ser encontrada na associação de executivos mais antiga do nosso espaço. $O$ confronto das entrevistas revela a superposição de dois tempos da atuação profissional, os quais, garimpados, mostram os sentimentos de duas posturas distintas face à sociedade.

Um dos antigos fundadores da Associação Paulista de Administração de Recursos Humanos (APARH) narrou-nos, em estilo heróico, as suas impressões sobre as primeiras reuniões informais dos chefes de pessoal, que queriam se aprimorar profissional e moralmente e filosofica e educacionalmente etc... levando à constituição da organização pela junção de vários grupos homólogos. Para ele, sua associação é um fim em si mesma, ela é a "grande escola que formou a nossa geração". Tanto isso é verdade, que, em seu depoimento, o trabalho de construção da associação de executivos é confundido com a sua própria carreira profissional. Reivindicando possuir mais de 70 diplo-
23. Seria interessante ler a disputa eleitoral entre Fernando Henrique Cardoso (FHC) e JQ visando à prefeitura da cidade de São Paulo em 1985 sob esta ótica. Afinal, mais do que nunca, FHC encarnou os novos agentes com seu discurso e apresentação "modernos", contrapostos aO de JQ de lapelas e gravatas largas e voz empostada, mas uma enorme capacidade de expressar subliminarmente 0 ressentimento daquela coorte.

24. ZILBOVICIUS, M.; FERRO, J.R.; GRUN, R. Novas estratégias patronais e novas respostas operárias: a Operação Vaca. Campos de Jordão: ANPOCS, 1986. 
mas de aperfeiçoamento, ele demonstra a típica postura de deslumbramento dos autodidatas frente à cultura. No mesmo tom, a definição que ele dá para o papel do profissional de sua área é a de "meio termo entre o capital e o trabalho", a pessoa que pode argumentar entre os dois extremos aparando as arestas e levar às partes o "bom senso que deve nortear o relacionamento entre as classes". Ao lado da epopéia da constituição da sua entidade, ele nos fala espontaneamente do primeiro automóvel que possuiu, um Skoda, na década de 50, "quando ter um carro não era para qualquer um, era um sinal de prosperidade". Ele conta-nos que aquisição estava acima de suas posses, mas como ele se encantou com o veículo, seu patrão lhe fez um grande adiantamento, posibilitando a compra. Ele foi chefe de pessoal daquela empresa durante uma boa parte de sua carreira e sempre "deu à empresa o melhor de si".

Em contraste aberto com a postura daquele seu predecessor, o então presidente da APARH (1988), gerente geral de recursos humanos de uma grande empreiteira, "não se abre sobre assuntos pessoais". Ele tem curso superior e defende a atuação do profissional RI (Relações Industriais - termo como pretendem ser chamados os agentes mais modernos do campo) como uma espécie de "consultor interno", que diagnosticaria problemas e "compraria as soluções junto aos consultores externos existentes no mercado". Ele acha que os profissionais de outras áreas têm razão ao criticarem RI por favorecer o inchaço do seu setor, opinião externada por agentes de outras especialidades e confrontada com nosso entrevistado tendo dado "uma importante entrevista à Revista Exame", colocando sua postura e assim, criticando indiretamente seus companheiros. Para ele, .0 administrador de RI deve estar "resolutamente ao lado do capital", trabalhando em sintonia direta com os objetivos da empresa. Ele acha que o "homem de RI" deve ser ouvido pelo governo, ouvido pela Constituinte ${ }^{25}$. Ele declara-nos, por fim, que um dos seus objetivos à frente da APARH prende-se a "poder fazer muitos contatos, se projetar, para mais tarde poder tornar-se um consultor independente .
Salta aos olhos a diferença de fairplay dos dois agentes em relação às organizações em que respectivamente militam e trabalham. $\mathrm{O}$ nosso primeiro agente autodidata não revela nenhum manejo na sua relação servir $x$ servir-se das empresas onde trabalhou ou da associação de executivos para cuja construção ele contribuiu. Já o segundo agente pensa nesta relação de forma mais simétrica. Ele coloca os seus interesses particulares acima dos interesse das organizações, aparentemente sem nenhum problema ético, declarando-nos que "... eu costumo dizer que ninguém faz as coisas só por altruismo, sem querer se beneficiar delas...". Claramente, ele serve às organizações na perspectiva de depois servir-se delas na alavancagem de uma carreira solo. Nosso primeiro agente, ainda que afirme ter construído a APARH e ter "...feito o setor de pessoal..." das empresas onde trabalhou, sente-se como se tudo devesse às organizações onde percorreu a sua carreira. Esta postura impede-lhe vislumbrar qualquer independência em relação às instituições. O seu autodidatismo, uma espécie de capital cultural de difícil reconhecimento, parece representar um pecado original que deve ser purgado para toda a eternidade. Assim, não lhe passa pela cabeça usar sua posição em quaisquer das entidades por onde passa ou passou para finalidades que não sejam absolutamente coincidentes com as das organizações. Tudo nos faz crer que este ator sente que seu destino pessoal mais provável teve uma carreira do tipo operário, já que “... não teve o estudo suficiente..." nem tampouco teve "...herança familiar...". A combinação destes fatores coloca o agente na legião dos funcionários. Por outro lado , nosso executivo da geração posterior sente-se possuindo um cacife próprio, uma capacidade de barganha individual frente às empresas e à associação de profissionais que permite-lhe declarar a céu aberto $e$ sem pruridos que pretende um futuro pessoal independente de ambas.

\section{A DIVISÃO CENTRAL}

Vimos que os dois agentes divergem sobre a postura básica do profissional da área, sobre qual deve ser a sua macroidentidade. Realçando as cores, o agente autodidata só declara a sua oposição às 
colocações de seu sucessor depois que o segundo se ausenta. Até então a entrevista começou conjunta e depois os indivíduos separam-se, a discordância estava implícita. Embora declarando-se fiel às empresas a que serviu, o nosso autor autodidata não as personifica nos seus donos ou acionistas e suas respectivas vontades arbitrárias, mas numa entidade metafísica onde deve prevalecer o bom senso. Os membros esclarecidos da empresa - seus funcionários qualificados - devem defender esta postura isenta, além dos interesses mesquinhos do trabalho e do capital. Este tipo de agente coloca sempre sua carreira em contraposição às carreiras operárias, sentindo-se uma “...pessoa que passou privações e soube superá-las com dedicação e gosto pelo trabalho..." podendo agora "...falar das coisas com conhecimento de causa..." Ele se declara um cidadão de classe média e para ele sua classe deve ser preservada porque ela protege a sociedade do caos que seria o enfrentamento direto entre o capital e o trabalho ${ }^{26}$. Já para o nosso agente da coorte dos executivos, o mundo não se divide entre possuidores de capital e de força de trabalho, mas entre pessoas mais ou menos capazes de conseguir uma boa inserção na sociedade.

Aparecem diante de nós dois sistemas classificatórios bem distintos, que aliçerçam visões de mundo e condutas pessoais também divergentes. Enquanto nosso agente da nova geração alicerça a sua postura na visão da estrutura social como uma mancha contínua sem barreiras intransponiveis e onde, portanto “... as chances estão por aí, são para quem quiser aproveitá-las...", nosso agente autodidata é bem mais pessimista. Ele vê um mundo mais segmentado, onde as possibilidades de cada um estão largamente predeterminadas por fatores incontornáveis e parte considerável do trabalho dos gerentes seria zelar paternalmente pelo menos capazes ${ }^{27}$.

As visões quase antagônicas marcam bem as diferenças na sua atuação profissional, explicando condutas quase diametralmente opostas, onde se chocam, esquematicamente, "cabeças feitas" principalmente pela herança patrimonialistaestamental da sociedade brasileira e pela "moderna" idéia de mercado. Para realçar as cores da análise, lanço mão de meu "depoimento do autor", já que fui posto vá- rias vezes em contato profissional com agentes homólogos aos entrevistados. Quando expostos a fenômenos de inquietação operária em geral ou greves em particular, agentes do estilo autodidata tendiam a insistir, nas reuniões entre gerentes que os operários. "... são uns coitadinhos, têm muitas necessidades e são portan-

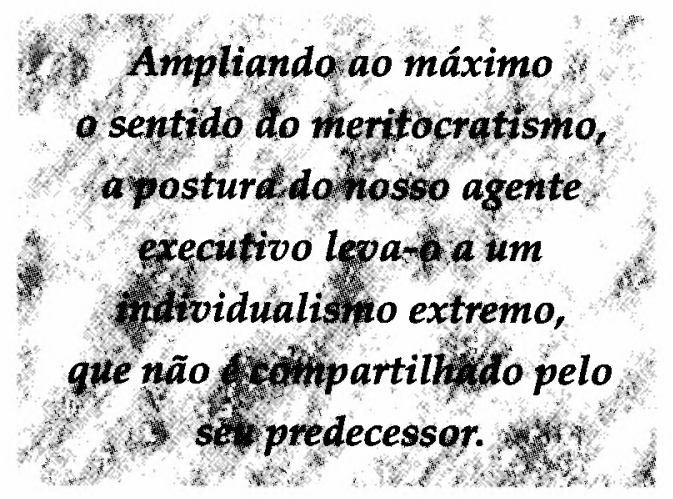

to presa fácil de sindicalistas com finalidades políticas...", enquanto agentes com o perfil de propriedades sociais do nosso segundo entrevistado se fixariam em interpretações mais duras, mas que reconhecem, à outrance, a capacidade de juízo próprio dos operários, como a declaração que se segue, que já escutamos várias vezes na mesma forma."...Eles (os operários) têm mesmo é sangue ruim..."

Agentes situados a meio caminho entre as duas influências, a maioria deles no início da década de 80 , quando observamos tais comportamentos, tendiam a encontrar explicações que integravam os dois pontos de vista. Apareciam versões eruditas deste cruzamento as quais, numa paródia provavelmente involuntária da Sociologia das Comunicações à Lazersfeld, diziam: “...Estes problemas se so' lucionariam mais facimente se conseguissemos eliminar da empresa os trouble masters..." ou numa versão mais "psicologista", inspirada nos estudos da equipe de Elton Mayo, os causadores de problemas seriam os "líderes negativos".

À primeira vista, pareceria paradoxal ver agentes de uma especialidade que foi promovida à agora executiva justamente por causa da inquietação operária, querer desvalorizar este fenômeno. Mas estas apreciações - frisamos, diante de executivos de outras áreas - pareciam mais influenciadas pela necessidade de se distin-
26. Numa amostra que recolhemos em GRUN, R. A produção de uma empresa moderna: os bancários $e$ a automação. $0 p$, Cit., na cidade de São Paulo, agentes deste tipo reivindicam uma origem próxima, européia ou japonesa, que the dava "... sangue bom para trabalhar honestamente e saber esperar pela justa recompensa...". 0 agente que apresentamos agora é em vários sentidos um homólogo daquela série. Entretanto, nada impede que, em zonas não tocadas pela imigração maciça, encontremos outro tipo de auto-identificação.

27. As visões do mundo dos nossos autores estão claramente sobredeterminados pelas suas trajetórias e pelo ponto delas onde eles se localizam no momento. Seria interessante, em, enquanto tema de uma pesquisa de cunho mais histórico, saber a interpretação da estrutura social que nos forneceria 0 autodidata num momento de auge de sua carreira ou, já no campo de ficção científica, as opiniōes dos nossos hoje gerentes triunfantes quando do caso de sua vida profissional. Poderíamos então analisar meIhor 0 peso relativo dos fatores origem e escolaridade que hoje encontram-se confundidos. 
28.GRUN, R. Quem é o moderno? Um estudo sobre as estratégias discursivas dos gerentes brasileiros. Revista Brasileira de Ciências, ANPOCS, nº 18, p. 96 108.

29. FOLHA DE São Paulo, p. F1, 03 jan. 1990.

30. Sobre as questões simbólicas abertas pela polissemia do tempo "executivo"e suas influências na estruturação da categoria e de suas relações com os empresários, ver GRUN, R. Quem é moderno? Um estudo sobre as estratégias discursivas dos gerentes brasileiros. $0 p$. cit. guir da massa operária do que de demonstar qualquer competência técnica específica. Diante da "naturalização das greves" pela sua repetição sistemática, podemos pensar no abandono de explicações menos "técnicas", embora a busca do trouble maker continue a ser aconselhada, como pudemos constatar, já no fim da década, em palestras destinadas a alunos em fim de curso de Engenharia de Produção, num aparente esforço para "desintoxicá-los" das posturas esquerdistas eventualmente absorvidas na Universidade.

\section{MÉRITO E MERCADO}

No tipo de relação que os dois tipos de agentes adotam nas organizações, podemos observar um exemplo da diferença de posicionamentos diante da sociedade como um todo que contribui para explicar algumas evoluções recentes dos padrões de sociabilidade das classes médias urbanas. Ampliando ao máximo o sentido do meritocratismo, a postura do nosso agente executivo leva-o a um individualismo extremo, que não é compartilhado pelo seu predecessor. Este, preso às malhas das organizações, só se sente existindo dentro e através delas.

Para nosso executivo, o mercado deve falar mais alto, decidindo o destino das pessoas de acordo com a sua capacidade. Não é assim, por acaso, que ele adota uma estratégia transparente de crescimento do seu capital cultural-técnico e social, para mais tarde tentar transformálo em capital econômico. Em nome desses ideais, as eventuais veleidades protecionistas de sua profissão devem ser exorcizadas. Ele advoga, principalmente para os negociadores trabalhistas e depois para os executivos em geral, que os executivos em geral, que os ajustes salariais devam ser discutidos fora da arena principal dos dissídios acertados com os sindicatos para não comprometer de nenhuma maneira as cúpulas da empresa com as reivindicações trabalhistas.

Podemos extrair, do âmago das posições dos agentes organizacionais vindos dos dois tempos que se sucedem, uma contraposição que ilumina uma das âncoras do novo liberalismo que o Brasil importa com sucesso dos países anglo- saxões. Novos agentes, fortemente dotados dos equipamentos cognitivos necessários para a atual sociabilidade organizacional, encontram numa espécie de laissez faire redivivo o melhor ambiente para fazer as suas propriedades. Nesta perpectiva, todos os posicionamentos que impedem a livre atuação do mercado devem ser sumariamente afastados, incluindo-se aí as veleidades protecionistas dos velhos agentes, numa versão simétrica das antigas patrulhas ideológicas da esquerda dos anos 70 . Num segundo momento, graças às transformações análogas no campo intelectual, essa visão ganha os meios de comunicação de massa, influenciando desta maneira setores das classes médias muito mais numerosos do que os agentes comprometidos diretamente nos conflitos organizacionais ${ }^{28}$.

Valores como seniority (termo empregado pelos agentes na sua versão inglesa) ou "vasta experiência" são aqui associados ao antigo protecionismo nas relações de trabalho e os nossos "lobos jovens" querem o sangue e a carne desta gente e principalmente as suas posições. Lutase desta forma pelo estabelecimento dos critérios de excelência legítimos no campo. Os velhos agentes ainda dispõem de muitos cargos e posições importantes, inclusive no "filé" da consultoria ${ }^{29}$. Por menos que gostem os novos, muitas empresas demandadoras de serviços de consultoria ainda procuram a segurança fornecida pelos profissionais dotados de vasta experiência. Podemos mesmo explicar a enorme diversidade de pacotes de consultoria organizacional, cada um com novidades aparentemente tópicas em relação a seus precedentes, pela necessidade de contrapor a novidade à experiência.

Os resultados desta luta simbólica travada no campo gerencial não são inteiramente decididos internamente. Assim, dentre as razões da força demonstrada pelos executivos na defesa de seus prejulgados, podemos encontrar um encontro com outra série causal, representada pela toada privatizante em que setores expressivos do patronado centram fogo. Este outro autor, dotado evidentemente de muito fôlego e influência, torna mais complexa a relação entre o campo executivo e o intelectual ${ }^{30}$. 


\section{O PÚBLICO E O PRIVADO}

Na seleção entre a vida privada e a vida pública aparecem grandes distinções entre os agentes.

Para o autodidata, esta divisão carece mesmo de sentido. No seu esquema de autojustificação, as mesmas qualidades pessoais - honestidade, bom-senso, eqüidade...- que fazem-no um homem de bem na sociedade são aplicadas na vida profissional, donde resultou a sua posição priveligiada. Por conseguinte, a sua vida pessoal não só é um livro aberto, como ele faz questão de mostrar as páginas e capítulos a seus interlocutores, já que elas simplesmente confirmam e realçam a sua posição e vocação. Neste contexto, a instância da "capacidade profissional" não adquire autonomia. O agente dá muita importância aos aspectos filosóficos e éticos de sua conduta profissional, não separando esses pontos do que seria a esfera do estritamente técnico. Quando ele conta-nos, orgulhoso, sobre seu Skoda, ele está fazendo passar a confiança e reconhecimento que o seu antigo patrão já lhe hipotecava nos estágios intermediários de sua carreira.

A ligação estreita entre o trabalho e a vida privada, numa ética que engloba e orienta explicitamente as duas esferas, característica dos agentes da coorte autodidata, é análoga à conduta do artesão, conforme descreve-nos C. Grignon ${ }^{31}$. Podemos explicar esta similaridade a partir da constatação da analogia entre as duas formas de aprendizado da profissão, ambas através de mimetismo, onde os atores aprendem (e apreendem) observando o trabalho de seus colegas mais adiantados na profissão. Absorvese inextricavelmente uma profissão e um estilo de vida. Dados os investimentos afetivos, realizados no circuito fechado dos códigos restritos, que os agentes engajam neste tipo de aprendizado, é ingênuo esperar qualquer autonomia das esferas propriamente técnicas do trabalho. Entretanto, para agentes socializados em gerações posteriores, quando o peso da educação formal na socialização do indivíduo é muito maior, a diferença entre a casa e a escola é evidente desde a primeira infância, inscrevendo assim nos agentes os esquemas cognitivos que os predispõem a enxergarem com nitidez as diferenças entre vida privada $e$ vida profissional.

Para o agente da geração posterior, a sua vida privada não diz respeito ao entrevistador. Ele se recusa absolutamente a dar qualquer dado sobre ela além dos "censitários" - idade, escolaridade, nú-

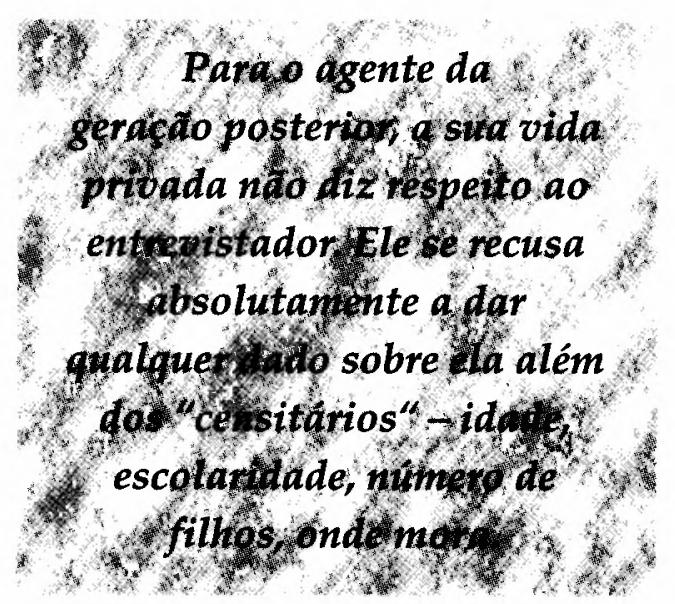

mero de filhos, onde mora. $\mathrm{O}$ contraste não poderia ser mais flagrante, enquanto o primeiro entrevistado fala da sua esfera privada mesmo sem ser perguntado, como se a sua relevância para o entendimento de seu relato fosse evidente, o segundo mantém um mutismo absoluto sobre o tema. Ele só fala de si através de sua vida profissional, das suas realizações nas empresas e entidades e de seus pontos de vista sobre aspectos da profissão, revestindo sempre a sua argumentação de justificativas técnicas consideradas relevantes em seu meio profissional.

Tipificando o executivo moderno, um grande momento na carreira do nosso segundo entrevistado - a julgar pelos colegas de especialidade, a sua consagração - foi a "...importante entrevista concedida à Revista Exame...". Embora já fosse Presidente da APARH naquele momento, ele se credita pessoalmente a distinção de ter sido chamado a opinar sobre as estruturas organizativas de $\operatorname{Re}$ cursos Humanos naquela Revista ${ }^{32}$. Aqui, a autonomização da esfera técnica parece total. Não cabem indagações sobre a sua vida pessoal, que nada tem a dizer a capacidade profissional do executivo.
31. GRIGNON, C. L'ordre des choses. Paris: Minuit, 1971.

32. A importância que os agentes concedem aos diversos órgãos da imprensa de negócios é difícil de ser avaliada por causa da influência pouco clara dos periódicos estrangeiros. Em todo caso, a Editora Abril, responsável pela Revista Exame, considerava, mercadologicamente, como os concorrentes para a veiculação de propaganda que tenha como alvo o público executivo, a revista Senhor e os encartes da Gazeta Mercantil. No momento das entrevistas, encontrei referências espontâneas somente a Revista Exame e aos jornais 0 Estado de São Paulo e Gazeta Mercantil. 0 efeito da concorrência interna no campo da imprensa pode evidentemente fazer mudar essas lembranças. 


\section{ÉTICA E ETHOS}

Os aspectos éticos da profissão parecem ausentes das preocupações do nosso executivo, numa postura que parece-me muito influenciada pela presença ainda relevante dos autodidatas na especialidade. Encontramos, entretanto, eco para as questões éticas em agentes das outras associações de executivos, as quais, além de congregarem especialidades mais reconhecidas do meio gerencial como finanças, marketing ou controle da qualidade, já surgiram num momento e em zonas do espaço gerencial onde os autodidatas no senso estrito estavam descartados.

Internacionalmente, o problema da ética parece ser uma preocupação crescente nos meios empresariais. Notemos que as questões éticas aparecem nos debates sempre que o ethos não é mais suficiente para ordenar as relações entre os diversos agentes de uma comunidade ${ }^{33}$. Quando os preceitos que regem a conduta não estão suficientemente interiorizados para conduzir espontaneamente a ação dos indivíduos, aparece a necessidade de se codificiar os preceitos de convivência geralmente aceitos pela sociedade. Com o aguçamento da luta no interior do campo ge,rencial, principalmente nos países centrais, mas escoando rapidamente para o Brasil e a penetração cada vez mais presente de códigos de conduta hiperindividualistas nas novas gerações de gerentes, o panorama do campo começou a ser abalado por escândalos seguidos. Agentes dispondo de todos os quesitos de respeitabilidade normalmente aceitos, punham em prática, nas relações entre iguais, métodos de conduta até então só admitidos nas relações com sujeitos periféricos ao campo, tais como agências governamentais de países subdesenvolvidos e que normalmente eram conduzidos por agentes bem definidos, tais como advogados não pertencentes ao quadro efetivo das empresas, para evitar o "contágio".

E claro que os meios econômicos não podem sobreviver à generalização das práticas "piratas", senão através de um aumento dos sistemas de controle, de custo econômico desporpocionalmente alto e de custo social em termos de legitimidade verdadeiramente incalculáveis. Por esses motivos bem concretos, mas também por uma emanação do ethos dos agentes mais antigos, formados em outros tempos do campo empresarial, aparece uma tendência a enfatizar a questão da ética no mundo dos negócios, introduzindo ou reavivando as cadeiras desta disciplina nas Business School. Entretanto, estas tentativas esbarram nas condições de socialização das novas gerações de gerentes, já que os alunos demonstram pouco interesse por esses cursos. Pilares morais da Era Reagen, como M. Friedman e I. Kristol, além do conhecido autor de literatura gerencial, P. Drucker, insurgem-se contra esta nova vaga, por eles considerada moralizante e esquerdizante, enquanto nomes importantes do business tais como John Ackers, Presidente da IBM, sustentam-na. Sociólogos organizacionais conhecidos, tais como D. Riesman, atacam a perigosa falta de moral das novas gerações, imputando-a aos procedimentos demasiadamente competitivos do sistema escolar norte-americano como um todo e particularmente dos jogos de empresa que são os típicos instrumentos de aprendizado nas escolas de Administração, que encorajam o florescimento de rivalidades selvagens entre os alunos. Também A. Etzioni, outro renomado teórico das organizações, intervém no debate, lamentando a onipresença do pragmatismo e de um empirismo grosseiro que se faz presente nos estudos através da rusticidade dos métodos quantitativos de gestão. Apesar desta galeria de questionamentos e questionadores ilustres, os alunos continuam no veio hiperindividualista, mostrando que a "Era Reagen" tem fundamentos sociais bem mais amplos do que se pensa ordinariamente ${ }^{34}$. A importação certa desta tendência para o Brasil, num meio empresarial onde a ética nunca deitou raízes profundas, mesclando-se com os vetores "indígenas" que agem no mesmo sentido, forma um caldo de cultura com a força explosiva de dez bombas atômicas...

\section{O MANEJO DA LEGITIMIDADE}

Os agentes que atingiram o ápice de sua carreira em épocas organizacionais sucessivas irão adotar posturas diferentes diante da entrevista e do entrevistador, que revelam a sua capacidade diferencial de prati-
34. Os dados sobre o debate estāo em Le Monde: affaires, $p$. 15,27 out. 1988 . 
car os "jogos da sociedade" a que podem ser reduzidos boa parte dos instrumentos comportamentais da administração ${ }^{35}$. $\mathrm{O}$ autodidata, que viveu o essencial de sua vida profissional num tempo em que sua ocupação era considerada subalterna, vê o interesse externo do entrevistador pela sua atuação como uma distinção gratificante, que de alguma forma consagra sua trajétoria. A situação é vivenciada de forma diferente pelo agente moderno. Ele está acostumado a dar entrevistas, e se não está realmente, ele "faz de conta", uma vez que faz parte da imagem do executivo bem arredondado dar entrevistas constantes. Ele faz questão de demostrar segurança em suas colocações demonstrando um certo enfado diante de perguntas que têm uma "resposta evidente".

Enquanto forma, a entrevista pode ser percebida como um instrumento que mostra o corte de modos de comunicação e de visibilidade da profissão no passar das gerações. A capacidade de vivenciála, que se apresenta diferencial, mostra a ponta de um iceberg constituído pelos milhares de gadgets manejados de maneira muito mais desenvolta pelos novos agentes. Sob uma forma "técnica", a entrevista faz reviver os antigos "jogos de sociedade", as conversas em que as "pessoas de bem" se reconheciam. A diferenciação na conduta dos agentes nesta situação se reconheciam artificial mas emblemática, não é um fato isolado, ela é percebida por todos os participantes do "jogo gerencial" como um potente revelador da posição "objetiva" de cada indivíduo nas hierarquias que cortam aquele campo. Através das entrevistas, não tanto pelo conteúdo explícito expresso pelos agentes, mas principalmente pelos indicadores subliminares que são fornecidos pela face demonstrada ${ }^{36}$, explicitam-se rapidamente aos olhos dos indíviduos bem socializados nas regras do campo gerencial, quem são os "executivos abertos e competentes, aptos a receber novas responsabilidades" e também quem são os "funcionários restritos, ultrapassados e que devem ser submetidos à primeira oportunidade".

\section{DIPLOMA E RESSOCIALIZAÇÃO}

A procura de propriedades diferenciais entre os agentes mostrou saliências tê- nues em termos macroestruturais, mas expressivas quando pensamos na mudança de modos de dominação que está em curso nas empresas. Os dois agentes começaram sua vida profissional no mesmo patamar. "...início é sempre o mesmo,..., somar as horas nos cartões de ponto,..., depois arquivista, depois escriturário, depois encarregado, dai CHEFE...".

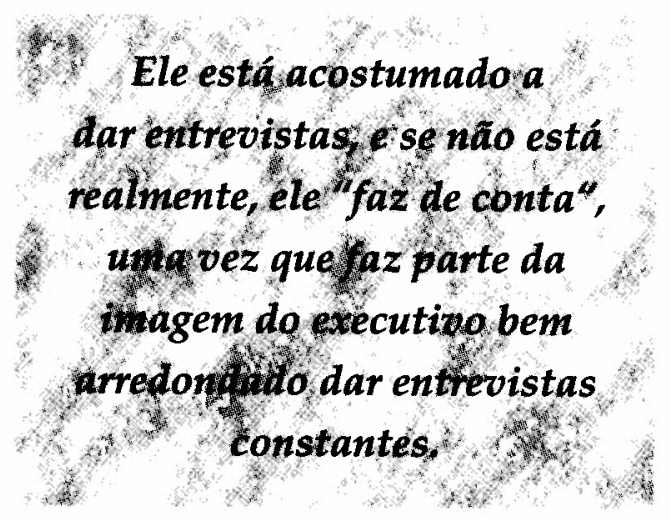

O corte temporal de 20 anos existente entre o começo da carreira de cada um deles - entre 1943 e 1963 - assinala o início e o fim de uma época econômica. Ainda que em termos organizacionais não se possa localizar nenhuma inflexão profunda entre aqueles dois momentos, a grande diferença será o ponto de maturidade de cada uma das carreiras. $O$ nosso segundo agente viveu-o num momento de abertura de possibilidades, a época do milagre econômico, quando ele foi capaz de pôr na mesa seus trunfos especialmente profissionais com a obtenção de um diploma de nível superior.

$\mathrm{Na}$ hierarquia das escolas superiores, $\mathrm{O}$ título do agente catalogado entre os executivos não parece ser muito importante, tanto que ele escamoteou o nome da escola quando perguntado.

Mas este é o passaporte para o novo modo de dominação. A posse deste título fornece, indiretamente, as disposições cognitivas para se conduzir na nova era, legitimando (e de certo modo também produzindo) as pretensões de seus detentores. $\mathrm{O}$ título escolar superior fornece, de uma maneira quase estatuária, as bases fundamentais a partir das quais os conhecimentos adquiridos nas carreiras profissionais podem se encaixar positivamente, pouco importando o conteúdo concreto dos ensinamentos efetivamente
35. VILLETTE, Op. cit.

36. GOFFMAN, E. Les rites d'irenteractions. Paris: Minuit, 1974. 
37. BORDIEU, P. La distinction. Paris: Minuit, 1979.

38. MARTINS, C. B. A empresa cultural no Brasil:: um estuto de caso no superior privado. São Paulo: PUCSP, 1979. (Dissertação de mestrado).

39. GRUN, R. Taylorismo e fordismo no trabalho bancário: agentes e cenários. Revista Brasileira de Ciências Sociais, São Paulo: ANPOCS, vol. 1, $n^{\circ} 2$, p.13-27, 1986.

40. WHYTE JR., W.H. The Organization Man. Nova lorque: Simon \& Schuster, 1956.

41. Ver Business Week, $\mathrm{n}^{0}$ 2971, 10 dez. 1986.

42. WHYTE, Jr., W.H. Op. cit. recebidos ${ }^{37}$. É claro que não encontraremos na Pedagogia, nenhum arrazoado interno que mostre o privilégio dos portadores de qualquer diploma de nível superior face aos seus detentores. Tanto isso é verdade que, baseados na evidente deficiência das instituições de ensino privadas que fornecem cursos de graduação noturna para a clientela que aspira à entrada no campo executivo, analistas do processo educacional brasileiro pontificam sobre a inutilidade daqueles cursos ${ }^{38}$.

Por si só, os títulos universitários de segunda linha não alavancam as carreiras de seus portadores. Entretanto, quando outorgados a agentes já inseridos no universo executivo, eles passam a dar uma espécie de cidadania e são lidos, tanto pelos seus portadores quando pelos seus concorrentes, como uma demonstração de sua vontade de progredir ou de espírito de luta.

Possuidores do "canudo", os agentes são considerados em condições de partilhar do novo léxico e principalmente do novo ethos organizacional. Mas esta integração é pela "porta dos fundos". Esses agentes, que alhures chamei de autodidatas reconvertidos, só conseguem acompanhar a trama da época parcialmente, como uma camada subalterna do campo executivo, apta apenas a ocupar os postos de menor prestígio ${ }^{39}$. Não é assim por acaso que os encontramos majoritariamente entre os RIs. Mas, a exemplo do nosso agente da geração anterior, os indíviduos que não possuem nem este diploma de nível superior "secundário", sequer conseguem entrar na agora executiva.

\section{INDIVÍDUO E ORGANIZAÇÃO}

A forma como os indivíduos concebem sua relação com as organizações oferecem a possibilidade de acesso a grandes transformações nas visões de mundo dos "homens-organização" médios de cada época. O primeiro agente, como antevimos, enxerga as organizações como entidades autônomas, que trancedem os indivíduos. O segundo lê as relações de poder vividas pelos indivíduos nas empresas e entidades como uma simples relação entre pessoas. Nosso primeiro agente mostra um perfil bastante próxi- mo do "homem-organização" descrito por Whyte Jr. ${ }^{40}$ nos Estados Unidos de 1956 - o agente moldado pelas organizações para servi-las fielmente em troca de uma carreira ascensional programada, lenta mais garantida. Este modelo de agente era ideal para uma época em que as grandes corporações norte-americanas dominavam totalmente a cena econômica mundial, sem qualquer perspectiva de abalos. Com a situação bem diferente no fim do século $X X$, o agente considerado como o ideal para as organizações também se modifica. Aparecem novos estilos de atuação, do qual o modelo yuppie foi a manifestação mais saliente nos anos 80 . Valores como "iniciativa própria" e "senso de antecipação", anteriormente considerados pouco adequados para os "bons funcionários" passam a fazer parte do elenco de qualidades positivas. Estas mudanças refletem a nova morfologia dos indivíduos médios recrutados pelas organizações, onde se destacam o aumento do nível de escolaridade médio e a melhor proporção entre os sexos.

O fenômeno yuppie pode ser considerado revelador de mudanças profundas no panorama gerencial dos países centrais. Uma descrição do campo aberto aos jovens que se engajam no campo executivo norte-americano na década de $80 \mathrm{mu}$ nidos do M.B.A., editada na Business Week, ${ }^{41}$ mostra um leque de alternativas onde os extremos são, de um lado as empresas multinacionais da "Corporated America", onde os agentes estão mais próximos do modelo de Whyte ${ }^{42}$ e do outro o mercado financeiro representado na Wall Street, que sinaliza para os jovens que sucubem à tentação de uma carreira rápida, mas em organizações menores e com pouca segurança de emprego. Destaca a revista que, mesmo no primeiro pólo, aparecem o que ela chama de fast track kids, jovens executivos "impacientes, irreverentes e sedentos por operações de ris$c 0^{\prime \prime}$. Esses novos agentes são considerados importantes para sacudir os gigantes empresariais americanos numa época difícil, embora não forneçam as provas de fidelidade ritual a que os antigos agentes se prestavam.

A exigüidade do universo executivo do Brasil faz cumprir uma clivagem análoga influenciada pelo exemplo norte- 
americano, mas não idêntica para dentro do mesmo espaço empresarial oligopolístico-multinacional. Aqui, as divisões se fazem dentro de cada empresa, potenciando os conflitos geracionais internos $e$ partindo duma relação entre executivos e empresas menos "leais". Segundo headhunters e executivos estrangeiros trabalhando nas filiais de empresas multinacionais que consultamos, a "infidelidade" do executivo brasileiro sempre foi maior do que a observada em outros países, mesmo antes do advento do yuppismo ${ }^{43}$. $\mathrm{O}$ apego dos jovens executivos brasileiros a aspectos exteriores dos padrões norteamericanos assinala mais, pelo que pude constatar, a tentativa de construção de uma barreira de distinção, expressa num gosto, numa forma de vestir-se, de portar-se, comer e beber marcadamente diferentes de seus predecessores, assinalando um esboço ainda pouco claro de conflito geracional intratitulados. Aí a divisão parece localizar-se dentro do universo dos executivos bem diplomados, onde os novos tentam assinalar a sua contemporaneidade mais marcada com os padrões internacionais, num mercado de trabalho que continua congestionado, sobretudo quando pensamos nos postos de alta direção.

\section{A CRISE DOS 40 ANOS}

Para acolher a chegada ao mercado das gerações mais novas, os mercados de trabalho gerenciais congestionados têm que eliminar seus indivíduos mais velhos, ou pelo menos parte deles. Numa zona de baixa regulação institucional, onde não existem salários profissionais garantidos por lei, é sempre tentador substituir os gerentes antigos, considerados ultrapassados por jovens recém-formados, ganhando inicialmente salários mais baixos, sem experiência profissional, mas maleáveis e dotados de fortes impulsos ascensionais que se revelam na vontade de apreender a cultura organizacional das empresas e os novos instrumentos de gestão.

A crise do envelhecimento executivo aparece para o público externo através dos relatos na imprensa dos gerentes deslocados de suas posições, principalmente no início dos anos 80 , época do primeiro grande impacto negativo da crise de ajustamento de economia à dívida externa, quando esses agentes encontravam sérias dificuldades para se reinserir em posições equivalentes às que ocupavam anteriormente. Os especialistas da área, ao mesmo tempo descrevendo, lembravam que... "ao eliminar esses agentes, as organi-

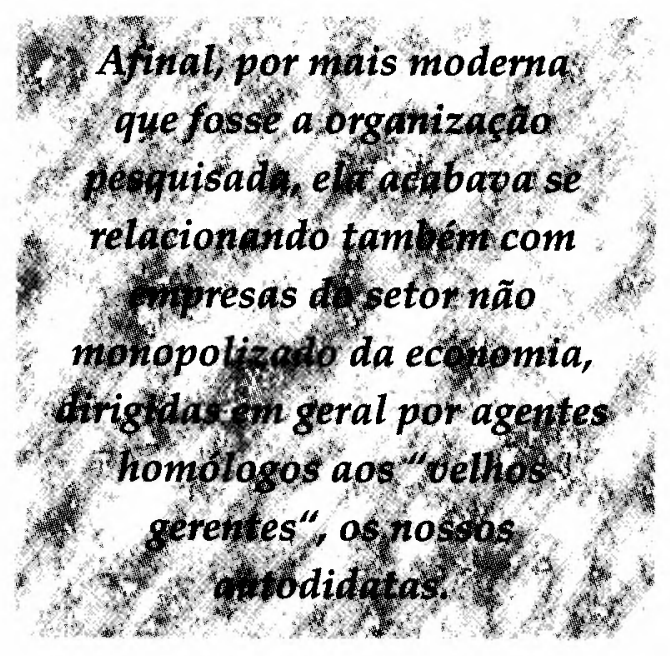

zações arquivavam também muita experiência $e$ feelings, necessários para o periodo de crise que elas estavam atravessando" 44 No quadro do conflito geracional, este tipo de colocação revela parte da realidade ao mesmo tempo em que esconde a sua essência. Em que pesquisa anterior, realizada entre gerentes comerciais de banco, compartilhei inicialmente daquela análise. Afinal, por mais moderna que fosse a organização pesquisada, ela acabava se relacionando também com empresas do setor não monopolizado da economia, dirigidas em geral por agentes homólogos aos "velhos gerentes", os nossos autodidatas (aliás, essas empresas acabam se transformando nos refúgios típicos daqueles agentes quando perdem seus em pregos nas organizações). Neste quadro de relações interempresas, todo o sistema cognitivo desenvolvido na trajetória desses agentes deveria ser fundamental para seu trabalho, onde eles poderiam exibir uma competência que seus concorrentes mais jovens não poderiam alcançar. Mas tais conhecimentos são intraduzíveis para a linguagem gerencial do momento, centrada em análises quantitativas extraídas de dados contábeis e projeções mercadológicas, que são instrumentos de gestão obrigatórios para as empresas mo-
43. Os interlocutores referiamse principalmente às mudanças constantes de emprego encetadas pelos executivos brasileiros.

44. JORNAL do Brasil, 28 dez. 1981. 
dernas, mas que nas empresas de gestão à antiga não passam de obrigações impostas de fora, realizadas ex-post-factum e portanto muito imprecisas.

Da mesma forma, as perspectivas de mercado dessas empresas não aparecem nas revistas de negócios - cujo conteúdo, afinal, é determinado pela interação entre dois tipos de agentes modernos, os executivos e os jornalistas. Assim, os feelings dos autodidatas não encontram um canal adequado para se expressar e qualquer problema na área sob a gestão de um agente daquela coorte acabava sendo interpretado como uma reiteração do que todos já percebiam: que "o velhinho precisa dar lugar a alguém mais técnico". Já os executivos mais jovens conseguiam se resguadar de fracassos equivalentes nas áreas que cobriam, documentando sua conduta nos moldes preconizados pelo banco e assim justificando as suas condutas ${ }^{45}$.

Um ramo da literatura especializada voltada mais diretamente para o "grupo de risco", lembra ao executivo que se aproxima da idade crítica que talvez o problema seja um excessivo apego à sua especialidade, quando é mais necessário uma "visão mais ampla" 46 . Revelando consistentemente uma faceta dos circuitos de consagração ao mesmo tempo econômicos e intelectuais do campo gerencial, os articulistas ao mesmo tempo fornecem seus conselhos para os indivíduos surportarem bem o peso da idade e anunciam a sua condição de prestadores de serviços especializados neste campo. Abrese um filão para um novo ramo de consultoria empresarial, os escritórios, de out-placement, onde serão oferecidos, entre outros serviços a "elaboração consiste de curricula" e "a determinação profissional de estrangeiros de obtenção de novos empregos". Os encargos referentes a estas atividades poderão ser suportados, seja pelo próprio gerente que busca uma nova colocação, seja pela empresa que ele trabalha atualmente ou que trabalhou e que pretende desligá-lo da forma mais indolor possível, mantendo a cumplicidade gerente $e$ empresa mesmo nestas situações-limite. Os conselhos explicítos, numa receita com dez passos, fornecida por um especialista da área ${ }^{47}$, visando a evitar que o executivo "envelheça precocemente" mostra-nos a trama destas empreitadas:
1. "Procure estabelecer opções profissionais, para o caso de você vir a ficar desempregado sem aviso. Mantenha relações pessoais com empresas de consultoria ou semelhantes, tomando conhecimento de como procedem, por exemplo.

2. Mantenha os seus conhecimentos profissionais e técnicos em dia, participando de cursos, simpósios, associações, bibliotecas, reuniōes, não apenas como ouvinte, mas ativamente, se possivel como palestrante.

3. Pesquise em livros estrangeiros sobre sua especialidade. Escreva sobre ela em revistas técnicas e órgãos de comunicação para a divugação.

4. Mantenha um ritmo de vida mais para o intenso do que para o acomodado. Seja participativo na empresa, no clube ou Igreja procurando dinamizar sua atuação junto aos colegas, grupos e amigos, como um todo no mercado.

5. Acompanhe o mercado de trabalho, mantendo o seu curriculum atualizado, procurando, se for o caso, a oportunidade de sua vida.

6. Leia diretamente jornais e revistas, para manter-se informado e ter suas opiniões, inclusive políticas, formadas. Não seja um Zé do Muro.

7. Tenha a sua auto-avaliação e autocrítica em dia.

8. Planeje os seus próximos cinco a dez anos de vida constantemente. Lembre-se que estão no passado as informaçôes que hoje você poderá bem utilizar para promover o seu futuro feliz.

9. Trabalhe junto com a familia; envolva a esposa na sua vida profissional. Não a mantenha alienada e na ilusão de que você é o máximo. Quando ela (ou você) descobrir que não é, o divórcio é o caminho mais freqüente. Os filhos devem conhecer onde o pai trabalha...

10. Não esqueça suas obrigações éticas com a comunidade, com o espírito religioso e com o seu próprio corpo (fazendo exercícios fisi$\cos ) . "$

O autor é diretor da Proselco - Recursos Humanos, especializado em recrutamento, treinamento e recolocação de executivos.

E fácil notar a dificuldade sentida pelos gerentes formados na época em que o exercício predominante da profissão era 
autodidata, afinal os mais fortes clientes em potencial destas empreitadas, em seguir os passos assinalados. Para esses agentes, vestir o figurino preconizado significaria um verdadeira "revolução ética". Vejamos porque, acompanhando o decálogo apresentado pelo autor passo a passo:

1.1."Por causa do grau de investimento afetivo empregado na sua carreira, em geral realizada em uma ou duas empresas apenas, o seu código de conduta não dá legitimidade para preparar defesas contra a firma em que trabalha;

2.1. Seu modo de aprendizado-padrão é essencialmente prático, sem mediações escolares. Custa-lhe portanto sair das situações abstratas de ensino para aplicaçōes concretas;

3.1. Quando muito, ele tem conhecimentos rudimentares de alguma lingua estrangeira, insuficientes para a leitura especializada. Além disso, muito provavelmente ele sequer sabe quais são as revistas especializadas de sua área;

4.1. Ele tende a colocar a sua casa e a sua família como um refúgio contra as pressões exteriores. Nada seria mais estranho do que franquear prematuramente a sua "última fronteira";

5.1. Mais uma vez, o "homem-organização" não pode acompanhar o mercado de trabalho. Além das razões expostas em (1.1.), porque ele é mais um "especialista" na sua organização do que em alguma especialidade definida pelo mercado externo;

6.1. Os jornais que ele lê têm como pontos de resistência principalmente o noticiário esportivo e de polícia. Mas, mais do que isso, para ele, as informações de negócios são as que vêem com o selo de autenticidade da empresa;

7.1. Ele está fazendo frente a toda uma empreitada de deslegitimação de seu modo de vida. Se ele abre aflanco para uma avaliação segundo os novos critérios, ele praticamente "desaba", até porque ele não reconhece a pertinência dos novos gadgets da administração;

8.1. Para ele a empresa tem, ou deveria ter, um plano de carreira justo e à medida de suas potencialidades. Seria uma pretensão absurda fazer um trabalho "paralelo";
9.1. De novo as razões de (4.1): podem-lhe que destrua a sua auto-imagem perante seus comandados: querem que ele repita as sessồes de psicodrama ou de mea culpa das igrejas Evangélicas;

10.1. Se ele seguir o conselho 10 , ele irá naturalmente procurar obras religiosas com as quais se identifica, mas por onde só circularão indivíduos análogos a ele e em situação profissional provalvelmente semelhantes."

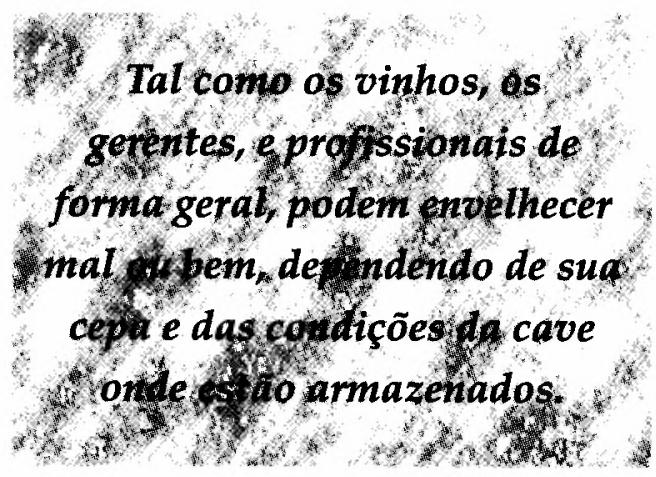

Mas o ardil da situação está além da inviabilidade dos conselhos a serem seguidos. Uma vez que eles formam claramente enunciados e tornados de domínio público, a atualização passa a ser responsabilidade exclusiva dos agentes em vias de ser "descartados". Afinal, a receita está explícita, é só segui-la. Passa a ser de sua responsabilidade pessoal a adaptação aos novos tempos. Se ele não detém as estruturas cognitivas básicas para empreender essa verdadeira conversão de alma, isto nem ele nem seus sucessores sabem explicitamente e se forem postos diante de um arrazoado deste tipo, irão ignorá-lo, pois ele seria contrário ao meritocratismo de que todos, mal ou bem compartilham. Então, o problema é apenas do agente autodidata, é pessoal e de um golpe é descaracterizando como problema social, como injustiça.

Nas situações organizacionais limite, onde a decadência equivale à expulsão dos "velhos", o afeito destes processos tem máxima visibilidade para o público externo. Mas a ressonância maior deve ser procurada em situações onde existe algum espaço para acomodações e onde, conseqüentemente, o impacto da desvalorização simbólica dos velhos gerentes apenas ajuda a deslocá-los das linhas de 
maior prestígio e rentabilidade das organizações. Processos deste tipo são freqüentes em empresas multinacionais de implantação relativamente antiga no país, que já mantém um corpo técnico titulado a tempo suficiente para criar "gerações de engenheiros" 48 ou empresas prestadoras de serviços públicos, que já mantêm, seu corpo técnico qualificado desde o início do século ${ }^{49}$. Nestes casos, a barreira geracional tem a virtude de aparecer isolada do fator educação, já que ambas as coortes partem de um mesmo patamar nominal de educação. Esta transparência deixa a questão ética mostrar-se com toda a sua nitidez. Na situação analisada por Zilbovicius, ela se exprime através da adaptação diferencial das gerações de engenheiros ao "japonismo", onde os operários passam a ser interlocutores válidos, mas reconhecíveis apenas pelos novos engenheiros ${ }^{50}$. $\mathrm{Na}$ segunda situação, surgem no campo, vindos dos quadrantes da militância política, os "engenheiros gestionários", que possuem uma nova visão da atuação da categoria, que os velhos engenheiros e uma parte dos novos submetidos ao poder de atração da velha cultura corporativa, estigmatizam como pouco técnica. Nestes processos, alavancam-se as carreiras dos agentes mais coetâneos simbolicamente com o novo modo de dominação e o capital cultural dos agentes socializados à antiga sobre um processo de depreciação acelerada.

\section{ENVELHECENDO E "AUTO-POESIS"}

O tipo de envelhecimento que significa obsolescência, incapacidade crescente, inadaptação, que marca os agentes mais próximos do pólo autodidata não

48. ILBOBICIUS, M. Op. cit.

49. GRUN, R. Trabalho manual e trabalho intelectual: algumas considerações a partir da situação empírica do Brasil dos anos 80. Rio de Janeiro: ANPAD, 1987.

50. É de se perguntar sobre os efeitos dos ecos do Movimento Estudantil sobre os novos engenheiros, aumentando a sua predisposição a reconhecer a cidadania das camadas populares e dos operários especificamente. minho onde estes agentes irão transcender as suas especialidades de origem e obter o rendimento máximo de seus capitais cultural e social acumulados. Já para outros, é a etapa do declínio, da incapacidade de se manter nos postos previamente alcançados.

Os indivíduos que possuem um grande volume de capital social e capital cultural bem certificado são os que mais resistem à prova do tempo, fazendo de suas dificuldades virtudes.

Tendo saído ou sido assimilados por setores ascensão das classes médias ou mesmo burguesa, eles gozam de uma capacidade nata de eludir suas eventuais deficiências. A sua competência técnica em geral não é questionada, os eventuais ponto cegos de sua adaptação aos tempos passa a ser lida tanto dos agentes que estamos descrevendo, quanto pelos seus concorrentes - todos submetidos à força de seu capital simbólico como meros detalhes que podem ser providenciados por especialistas. $\mathrm{O}$ conceito de especialidade passa assim por uma depreciação, enquanto que os nossos "agentes executivos" devem apenas se preocupar com as "questões de fundo". Reencontramos desta forma os nossos administradores estratégicos.

Longe de ser um obstáculo para o vivenciamento de novas situações, a trajetória passada daqueles indivíduos fornece-lhes o acúmulo de experiência que se soma à sua formação, levando-os a poder generalizar os fenômenos do cotidiano em transformação, entendendo a sua direção geral, vislumbrando assim as estratégias de melhor adaptação das empresas à realidade externa. A sua maior probabilidade de pressentir as novidades advém de sua rede de relações sociais, onde as novidades deverão circular primeiro. A legitimidade de sua formação cultural impusiona o vislumbre das possibilidades de atualização, ao mesmo tempo que os compele a atualizarem-se (noblesse oblige). A ação das propriedades sociais detidas cria assim uma dinâmica interna às personalidades que leva esses indivíduos a se adaptarem rápida e eficientemente aos novos tempos através de uma magia análoga à da acumulação do capital econômico. 
Os perfis mais típicos dos agentes agrupados nas organizações executivas ficam a meio caminho entre os autodidatas e os administradores estratégicos. Seus títulos escolares não são em geral absolutamente legítimos e seu capital social de origem é de baixa intensidade. Mas seu esforço associativo produz uma energia social não negligenciável, criando uma espécie de "micro-clima de cave" que aumenta suas possibilidades de bom envelhecimento. Observando novamente os dez passos sugeridos pelo especialista em out-placement, veremos que as associação de executivos fornecem aos seus quadros a ocasião de praticar a maior parte do breviário preconizado de uma forma legítima. Eles estarão constantemente colocados diante da possibilidade de atualização técnica pelo menos das novidades gerenciais mais evidentes, que circularão com bastante probabilidade nas rodas das associação de executivos. Como eles são gerentes vindos de várias empresas de ramos de negócios e origem estrangeira diferentes, a possibilidade estatística de aflorarem nos seus círculos, trazidas por algum dos seus diferentes membros é muito grande. A mesma coisa acontece para o capital social. Os handicaps de origem são parcialmente contornados pela concertação inter-pares, fazendo circular com maior rapidez as modas e os atributos mais rentáveis socialmente - o que é essencial para garantir o seu caracter distintivo. Atividades como os "exemplos de sucesso" ${ }^{51}$ dos RIs fazem crescer a segurança e a legitimidade dos nossos atores que possuem propriedades sociais de "média intensidade" na absorção dos modos de agir que são próprios dos indivíduos de extração social mais elevada. Tanto no sentido social quanto no sentido cultural, a caução dos colegas da especialidade funcionam aqui como um amparo, mais fraco do que as certezas apreendidas na primeira infância e na adolescência nas famílias e escolas de prestígio, mas que é suficiente para exorcizar o fantasma do envelhecimento precoce e manter nossos agentes no páreo desta dura disputa.

A composição das atividades das associação de executivos aponta-lhes uma posição ímpar no campo gerencial, mos- trando que elas combinam atividades de formação continuada, que poderíamos chamar de técnicas com atividades propriamente sociais, no sentido das colunas sociais. Na esfera técnica, as associação de executivos competem num mercado difícil, onde existem "pesospesados", como as empresas de consultoria norte-americana e as ofertas inter-

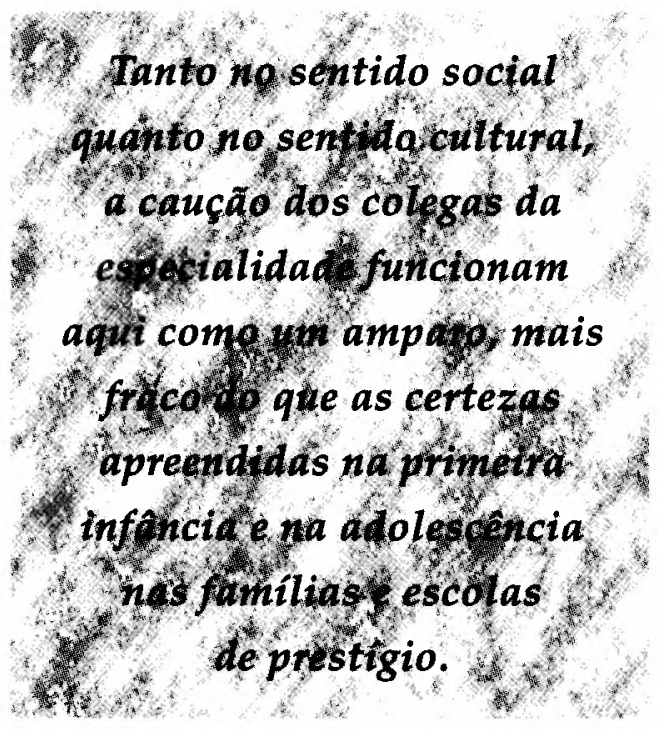

nas às grandes empresas. Enquanto produtores de capital social, o mercado é menos explícito, mas não menos concorrido e completado. Temos uma gigantesca rede de clubes, condomínios de lazer, escolas privadas etc., em geral de formação recente e com uma clientela ainda não institucionalizada. Desta forma, as opções listadas são bastantes complacentes para receber os recémchegados, onde se incluem os gerentes. As transformações na paisagem urbana da cidade de São Paulo e imediações agem no mesmo sentido. Surgem vários bairros novos para acolher membros das novas classes médias, sem nenhum controle maior de origem que não o habitus de seus moradores ${ }^{52}$. Poderíamos mesmo contar a história recente de bairros como a Moema, o Brooklin e o Morumbi a partir das estratégias de reconversão da classe média alta de São Paulo. A originalidade e o sucesso das associações de executivos podem ser explicados pela articulação dos dois eixos, produzindo a concertação institucionalizada tanto social quanto cultural das estratégias dos agentes. $\square$
51. Os "exemplos de sucesso" são experiências relatadas por "RIs" em seus grupos informais de pares, onde o narrador em geral um dos membros mais bem-sucedidos da confraria episódios de sua atuação na empresa no qual ele realça a sua defesa bem-sucedida do "ponto de vista" de RI face às posições dos demais executivos da empresa. Ver a respeito DUTRA, J.S. Profissionais de recursos humanos. São Paulo: EAESP/FGV, 1987. (Dissertação de Mestrado).

52. Os esquemas de venda dirigidos, empregados em empreendimentos como "Alphaville" podem indicar uma tendência num sentido contrário como uma espécie de reação ao controle social de origem das vizinhanças. Certamente esta questão mereceria um estudo aprofundado. 